\title{
SCHOOL HYGIENE AND EUGENICS: THE ROLE OF PHYSICAL EDUCATION IN REGENERATING THE "BRAZILIAN RACE"
}

\author{
Karl M. Lorenz, Ed.D. ${ }^{1}$ \\ Sacred Heart University \\ U.S.A.
}

\begin{abstract}
:
From 1870 to 1930 , physicians, writers, anthropologists and educators discussed the relationship between education and the less-privileged segments of the Brazilian population. Among ideas circulating in the late nineteenth century were precepts of School Hygiene, such as physical exercise could promote personal health and, in a broader sense, the total development of the child. In discussions of eugenic themes in the early decades of the twentieth century, Physical Education was further promoted as a corrective measure for the negative effects of miscegenation; that is, the physical, intellectual and moral debilities of the poor and non-white segments of the Brazilian population. This paper examines the nature and effects of the school discipline Physical Education on the less-favored children of Brazil by first introducing its role in School Hygiene and then by focusing on its extended role from the eugenic perspective. In this latter discussion, the racial ideas of Fernando de Azevedo regarding the regenerating effect of Physical Education on the "Brazilian Race" are explored.
\end{abstract}

Keywords: Education, History of education, School Hygiene.

\section{A HIGIENE ESCOLAR E A EUGENIA: O PAPEL DA EDUCAÇÃO FÍSICA NA REGENERAÇÃO DA "RAÇA BRASILEIRA"}

\section{RESUMO:}

Entre 1870 e 1930, médicos, escritores, antropólogos e educadores discutiram a relação entre a educação e os menos-privilegiados da sociedade brasileira. Entre as idéias em circulação no final do século XIX constaram os preceitos de Higiene Escolar e da inserção da Educação Física no currículo escolar entendida como uma matéria escolar que promoveria a saúde pessoal e, num sentido maior, o desenvolvimento integral da criança. Com o aumento dos debates sobre a Eugenia nas décadas iniciais do século XX, a Educação Física foi eleita como uma medida corretiva dos efeitos negativos da miscigenação; isto é, as debilidades físicas, intelectuais e morais manifestadas pelos segmentos pobres e não-brancos da população brasileira. Este trabalho examina a natureza e os efeitos da matéria Educação Física com relação às crianças menos-favorecidas do Brasil, primeiro sob a ótica da Higiene Escolar e depois sob a perspectiva da Eugenia. Nesta discussão, são exploradas as idéias raciais de Fernando de Azevedo sobre a Educação Física como agente regenerador da "Raça Brasileira".

Palavras-chave: Educação, História da Educação, Higiene Escolar. 
During the period known as the First Republic (1889-1930), different segments of Brazilian society sought to define the "Brazilian race." Their efforts originated from a larger concern about the most efficacious ways to politically and socially modernize the country and create a new model of society. Increasing urbanization, industrialization, abolition, and an expanding school-going populace were important factors that shaped discussions on economic and social issues in the waning years of the Empire (1822-1889) and the first years of the Republic.

The question that perplexed those struggling with these issues was how could a country endowed with vast national resources like Brazil experience such a slow pace of economic and social development? As expected of such a broad question, numerous explanations were offered. Among these, and one that was prominent in influential intellectual circles, was the racial constitution of the Brazilian people. Race, it was argued, was the key determinant of social progress and national development (VECHIA \& LORENZ, 2009, p. 58).

The identification of race as a factor in social progress and national development is not surprising given that since the mid 1800s the Brazilians were familiar with racial theories circulating in Europe. The theories first gained prominence with the studies of the British scientist Francis Galton (1822-1911) and the publication of his 1865 article Hereditary Talent and Character and his 1869 book Hereditary Genius. Galton meticulously recorded the physical characteristics of humans and concluded that a large number of physical, mental and moral traits were inherited and that progress could be achieved by the conscious selection and transmission of a population's hereditary endowments to future generations. Galton coined the word "eugenics" in 1883 in his Inquiries into Human Faculty and its Development to denote the science of the biological improvement of humankind. The eugenics doctrine encouraged the reproduction of superior individuals and races while discouraging the reproduction of those that were inferior.

The eugenics movement proliferated from 1890 to 1930 in more than thirty countries, each adopting the Galtonian paradigm and adapting it to its scientific, cultural, instructional and political objectives. In England, Germany and the United States, for example, the movement was particularly vocal in asserting a sense of white Anglo-Saxon superiority (SCHNEIDER, 1990, p. 176). Historically, however, the varied eugenics movements generally adopted either a neo-Mendelian or a neo-Lamarckian viewpoint when discussing racial issues (ADAMS, 1990, p. 3).

Regarding the neo-Mendelian approach, the Austrian monk Gregor Mendel cultivated pea plants in his Monastery's garden between 1856 and 1863 and carefully analyzing their characteristics. His observations lead him to propose the existence of dominant and recessive traits in the plants and hereditary units that carry these traits. In Mendelian science, then, unknown physiological mechanisms in species dictate the appearance and disappearance of assertive and non-assertive traits that are subsequently passed on to the next generation. In the late 1920s and early 1930s his work was extended to provide the foundation for the modern science of genetics, and its offshoot, eugenics. In the neo-Lamarckian approach, on the other hand, the renowned French zoologist Jean Baptiste Lamarck proposed in 1809 that an organism, in seeking harmony with its 
surroundings, experiences anatomical and physiological changes as a response to the demands of the environment. These newly-acquired characteristics are then passed on to the offspring. Lamarckian science identified the environment as the causative factor in the transformation of organisms.

Eugenics presupposed the existence of "superior" and "inferior" races, regardless of which paradigm predominated. Depending upon the eugenicist's point of view, neoMendelian or neo-Lamarckian, either genetic mixing or the environment, explains positive and negative racial traits. In Brazil, the Lamarckian paradigm prevailed, even though its rationale was often phrased in Galtonian terminology or explained in terms of Mendelian laws of inheritance (STEPAN, 1990, p. 121).

\section{Eugenic Discourse in Brazil}

In the second half of the nineteenth century racial ideas circulated in Brazil and fixed the notion for many Brazilian intellectuals that the great challenge of nationhood resided in its people. Count Gobineau's influential text promoting the racial theory of the superiority of the "Aryan race," Essai sur l'inégalité des races humaines (1854), was one of the first works known to the Brazilian elite. His ideas supported the thesis that the Brazilian race was primarily comprised of the poor and non-white segments of the population and that these were responsible for the social misery of the country and the slow pace of national progress. Other social and scientific texts by Buckle, Kidd, le Bon, Lapouge, and social Darwinists held up Brazil as a prime example of the "degenerative" effects produced by "promiscuous racial miscegenation." Brazilians found themselves receptive to these writings, especially those that espoused the apparent inequality of races in terms of a hierarchy constituted of "evolved" and "primitive" typologies. Theories of Negro inferiority, mulatto degeneration, tropical decay and their effects at inhibiting progress were accepted by many of the political and social elite (STEPAN, 1990, p. 114).

Questions about the origin and nature of the Brazilian Race were explored in the national literature, often in publications that voiced eugenic themes and employed eugenic terminology. Sílvio Romero, in his 1888 masterpiece Historia da literatura brasileira, discussed the mixing of the white, Indian and Negro peoples in Brazil, estimated a timeframe for the general whitening of the Brazilian people, and even advocated European immigration to hasten the "whitenening" and "homogenizing" process (ROMERO, 1906, p.123). Euclides da Cunha, in his novel Os Sertões, tells of the 1896 rebellion in Canudos, in the backlands of the northeastern tropical state of Bahia. He reflects on its causes and identifies the prejudicial effects of racial mixing on the behavior of the rebellious mestiço sertenejos (mestizos of the backlands) as one of a constellation of causes. The Bahian physician and ethnographer Nina Rodrigues, in Mestiçagem, Degenerescência e Crime (1899), defended the idea of the inferiority of the mestizo and the Negro and suggested they be subjected to their own penal codes. Towards the end of nineteenth century the historian Joaquim Maria de Lacerda decried the "black race" as "much less civilized and intelligent than other races", and prior to 1930, the novelist Afrânio Peixoto asserted that mestizos were the problematic offspring of the mixing of superior and inferior races. 
Most revealing was the racial view of the Brazilian writer Monteiro Lobato (18821948) who describes his disagreement with four inhabitants of the sertão (backlands of Brazil) in a letter to his friend Godofredo Rangel. The letter, which was published in the Journal of São Paulo in 1914, collectively referred to these "four lice" as a fictional and symbolic figure named Jeca Tatu - or "Jeca the backwoods hog" (the armadillo) - thus creating one of the best known literary characters of Brazilian culture. Jeca represents the typical country hick - a poor, ignorant, unpleasant and disease-ridden caboclo (an individual of mixed European and native Indian blood). Monteiro writes of his indignation with the apathy and indolence of the sertenejos, who because of miscegenation were a "veritable plague on the earth." Even though later Lobato revised his thinking and attributed the decadence of the hybrid Jeca Tatu to his poor economic conditions, the image of the degenerate mestizo became deeply etched in the minds of Brazilians (VECHIA; LORENZ, 2009, p. 61-62).

The formal incorporation of eugenics in Brazilian intellectual discourse was further advanced with the founding of the São Paulo Eugenics Society in 1918 by Renato Kehl and Arnaldo Vieira de Carvalho. The organization intended to study questions about heredity, lineage and evolution for the purpose of conserving and improving the human race (STEPAN, 1990, p. 67-79). Mounting interest in eugenics prompted the founding of the Eugenics Institute in Rio de Janeiro in 1928. The Institute aggressively addressed racialist issues and organized the First Brazilian Congress of Eugenics held in Rio de Janeiro in 1929 (MASIERO, 2005).

Interest in eugenics was also evidenced in an increasing number of books, pamphlets and periodical literature published on racial themes. Diverse publications infused their discourse with abundant references to health and sanitation, and references to Galtonian "dysgenic" and "eugenic" factors, fitness and unfitness, and hereditary defects (STEPAN, 1990, p. 117). At the heart of many of these writings was the belief that the "Brazilian Race" was constituted of poor and non-white populations - Negros, mulattos, and caboclos (descendents of whites and indians) - and that they were responsible for the social misery of the country. It was held that these less-privileged classes demonstrated physical, mental and moral problems, such as general debility, anemia, rickets, indolence, laziness, a violent disposition, homosexuality and prostitution, all of which were attributable to "racial degeneration" (VECHIA; LORENZ, 2009, p. 62). This negative characterization of the poor and non-white populations was wide spread and often voiced in pejorative terms in official documents, the press and national literature. Descriptive terms such as "degenerates, abnormal, ignorant, uncivilized, ugly, lazy, anarchists, brutes, irresponsible, drunks, decadent, noxious, marginal, dirty, libertine, parasites, vice-ridden, thieves and criminals" summarized a prevailing view that was extended to the children of the less-favored classes (ZUCOLOTO, 2007, p. 9).

\section{Physical Education and School Hygiene}

Themes about race and miscegenation were openly discussed in social, political and literary venues during the final decades of the Republic. Many believed that if economic 
and social progress was to be attained, intervention was necessary to "regenerate" the Brazilian race, and that the school was a suitable locus for this enterprise. The first variations of this theme appeared in Brazil circa 1870 with the proposal that less-favored children be educated in "hygienized" schools.

Interest in School Hygiene was a ubiquitous phenomenon in Europe and the Americas in the nineteenth century. Hundreds of books on the subject were published in Switzerland, England and France in the 1870s and 1880s. Many of the works advocated measures for promoting the total well-being of the student though the "hygienization" of the school environment. Influential works familiar and available to Brazilians included L'Education physique des garcons (1870) by Fossagrives; Hygiène des écoles; conditions architecturales et économiques. (1874) by Guillaume; Conférence sur le mobilier de classe, le matériel d'enseignement et les musées scolaire (1878) by Bagnaux; A treatise on hygiene and public health (1879) by Buck; Éclairage diurne dês écoles (1880) by Javal and Hygiène scolaire; influence de l'école sur la santé des enfants (1882) by Riant. These works characterized School Hygiene as a science that dealt with the physical, intellectual and moral well-being of students. Many of the principles they advocated addressed care of the body, sanitation and healthy environments, schoolhouse architecture, school furniture, materials and artifacts, the teacher-student relationship, student learning practices, and morality enhancing literature (LORENZ, VECHIA; FERREIRA, 2008).

School hygienists agreed with the general principle that a healthy and vigorous body makes for a healthy mind and spirit, and that the positive qualities of body, mind and spirit could be developed in students through the "engineering" of the school environment. Faced with the realities of an expanding number of non-elite students Brazilians were lured to this science because of its potential for developing strong, robust, pure and wise individuals (GONDRA, 2000, p. 535). The Brazilian statesman Rui Barbosa explained that indeed this was possible because "the entire regimen of school hygiene is subordinated to scientific laws, whose infraction victimizes new generations, and which would be the first interest of a country: the vitality of the race that populates it" (BARBOSA, 1982, p.50-51).

Central to the science of School Hygiene was the notion that the school attends to a "sick" population and that it often contributes to its physical decrepitude and demoralization (LIMA; HOCHMAN, 1996). Critics contended that poorly constructed schools, inadequate lit and ventilated classrooms, badly designed desks, and improperly formatted reading materials induced or aggravated common childhood afflictions such as near-sightedness, nosebleeds, headaches, curvature of the spine and rickets. In response, some argued that windows in the classroom be more propitiously located to enhance penmanship skills. Others suggested that compendiums and manuals be carefully formatted to facilitate reading and reduce ocular problems. Hygienists calculated the best distribution of the student's personal workspace and designed classroom furniture that would not force student into unnatural, contorted positions. These and other measures were meant to contribute to the general health of the student.

Some believed that the school not only caused and contributed to the ill-health of the student, it also aggravated congenital weaknesses. At the turn of the century theories of School Hygiene explained the origin and prophylaxis of health problems of the schoolgoing populace, often employing racial themes and terminology. An example of this "new 
think" appears in an 1898 doctoral thesis of the School of Medicine of Bahia. The author, Patury, defines the objectives of school hygiene as "regenerating character, combating vices, nullifying individual interests and transforming them into collective interests, inculcating a commitment to duty and love of work, creating a national sentiment and perfecting the race". In this and other doctrinaire treatises the influence of racist theories was wedded to an intent to perfect the Brazilian race (ZUCOLOTO, 2007, p. 90). Clemente Ferreira articulated this view at the Latin American Congress of 1909. Ferreira argued that the physical deterioration and "bastardization" of the Brazilian race resulted in school-age children who suffer from attitudinal and physical debilities that were essentially hereditary in origin. He notes that "the school environment frequently exercises a reinforcing influence on the defects and deficiencies, especially at the pre-school level, because of poor hygiene of the buildings, of the insane conditions of the classrooms and the anti-physiological way that school work is conducted, both from the mental and physical point of view" (MONCARVO FILHO, 1926, p. 192).

Towards the end of the nineteenth century Brazilian authorities advocated making Hygiene a topic of study in the curriculum and including health-promoting activities through gymnastics and physical exercises. Gymnastics and other physical educational activities were perceived to contribute to the health of students. It strengthened bodies and the will and focuses the mind. It prevented certain physical maladies, such as rickets. Strenuous exercise could even lessen the practice of masturbation, which provoked "physical annihilation", perverted the moral sense, and reduced intelligence (GONDRA, 2000, p. 536). The ameliorative effects of physical exercise on innate and congenital debilities were more thoroughly considered in the next century.

\section{Physical Education and Eugenics}

The idea that Physical Education could be a corrective measure applied to the lessfavored populations in Brazil was forcefully argued by Fernando de Azevedo (1894-1974) in the early decades of the twentieth century. Azevedo was a sociologist, an educator and Director of Public Instruction in Rio de Janeiro, and a vigorous advocate of the New School Education movement. He also was a member of a coterie of intellectuals who were committed to Brazil's elevation to modern statehood through the regeneration of the "Brazilian race." Ever an articulate advocate of racialist principles, he produced a significant amount of literature that looked at Brazilian education through the prism of eugenics.

Azevedo became the first secretary of the Eugenics Society of São Paulo in 1918. The Society was founded on the belief that there existed a "Brazilian race" constituted of the non-white segments of the population -- blacks, mestiços and caboclos. The thesis held these poor and non-white "types" demonstrated congenital physical and moral weaknesses; that "neurasthenic mestizos" suffered from generalized debility, anemia, rickets, indolence, laziness, violence, homosexuality and prostitution as a consequence of the miscegenation of Europeans and Indians, and European and Negroes. Other Members of the Society who adhered to this view represented the medical and professional elites, such as Belisário 
Penna, a sanitation expert; Vital Brasil, a bacteriologist of the Butantan Institute; Arthur Neiva, a microbiologist from the Oswaldo Cruz Institute in Rio de Janeiro; and Luis Perreira Barreto, a well-known physician and Comtean positivist.

The causes for the debilities found in the "Brazilian race" were believed to be congenital, but economic and social conditions were not discounted. Azevedo addressed the implications of these influences when dwelling upon the organic and social misery of young mestizos: “...these anemic children ... show in their apathetic sadness, sunken eyes and dull look... the effects of the social environment that defined them ... I speak in the name of these stunted and anemic children, almost ragamuffins, who fill a large number of the public schools ... and reveal in their apathetic sadness, in their deep shadowed and lackluster eyes ... the mark of the society that defines them, and the signs of congenital debility. Afflicted by hereditary defects and the penury of unhealthy surroundings, they are easy prey to the contamination of the environment" (AZEVEDO, 1932, p. 50).

The implication in this depiction is clear. The biological weaknesses and moral degradation suffered by the country's poor can be redressed if the environment is changed. One way to achieve the regeneration of the Brazilian people is draw upon educational resources to maximize the positive qualities of the child, to strengthen his physical forces. In his book On Physical Education: what it is, what it has been, and would it should be (Da Educação Physica: o que ella é - a que tem sido - o que deveria ser), published in 1915 and again in 1920, Azevedo attempted to reconcile the "hardened" neo-Mendelian branch of eugenics, that almost exclusively assigns racial factors as the cause for the debilities of the Brazilian people, with the "softer" neo-Lamarckian branch, that argued that these could be neutralized by changing in the environment. He suggested that negative racial propensities could be corrected through a strenuous program of physical education in the schools.

Azevedo's conviction that structured physical activities could have a positive formative effect on the individual presupposes a vital connection between a healthy body and a healthy mind; a relationship, he reminds us, that is acknowledged in philosophical and theological treatises. The cultivation of a strong and healthy body contributes to the development of positive intellectual qualities and moral virtues. In a weak or diseased body unfocused thought, a lack of energy, a propensity towards melancholy and eccentric aberrations prosper. Physical exercise excites the "gray matter of the nervous system." It requires the student to use "all of his endowments to overcome anatomical anomalies and nervous excitability, to eliminate the moral conditions leading to timidity, fear of action, dispiritedness and loss of will power; and to cancel the social proclivities resulting in timidity before others, disdain for others, neurasthenia and susceptibility for moroseness" (AZEVEDO, 1920, pp. 22-24). Programmed physical activities eliminate these deficiencies by inducing positive changes in the anatomy and physiology of the individual, which over time are assimilated by later generations.

Azevedo also underscores the salutary effects of Physical Education on female students. He argues that the physical regeneration of the woman is the most logical and direct way to ensure the development of healthy and robust Brazilians. Without the "refinement of her organism" the woman would be "an unconscious instrument for filling the world with unhealthy children and for adulterating the race though hereditary 
accumulation and the long process of physical degeneration" (AZEVEDO, 1920, p. 101). Azevedo reminds us that "the girl that blossoms [is] the mother of tomorrow;" and that to physically develop the woman of today "is to shape a future generation" (AZEVEDO, 1920, p. 98). He is emphatic in his belief that "strong women make a strong race; that the weakness of mothers begets the weakness of men, and that no endurable social progress is possible if women are not involved in the task of regenerating the race" (AZEVEDO, 1920, p.99). The physical regeneration of the Brazilian woman through programmed physical activity guarantees future generations of healthy and robust Brazilians.

\section{Final Comments}

Brazilian intellectuals were predisposed to adopt an environmental view of eugenics in which sanitation and hygiene, in their most encompassing sense, were linked. The experiences of Brazilians with School Hygiene practices, the impact of public health policies and successful sanitation campaigns in the late 1800s, and the participation of physicians, health workers and researchers, and sanitation experts in Eugenics societies in the early 1900s influenced decisions by civil and educational authorities about the way to approach student health. As Brazilians engaged in more vigorous debates about the physical and social miseries of racially mixed segments of the population in the first decades of twentieth-century, themes of School Hygiene were incorporated in discussions about the education of mestiços, mulatos and caboclos. The Brazilian eugenics movement of the 1920s and 1930s affirmed the relationship between eugenic theory and health, and hygiene and sanitation. As Stepan (1990, p. 121) has observed, "Structurally and scientifically, Brazilian eugenics was broadly congruent with the sanitation sciences and was interpreted by some as simply a new "branch" of hygiene.

Fernando Azevedo expressed his commitment to this idea in a 1933 interview recorded in the Journal of Physical Education and titled "The problem of regeneration" (O problema da regeneração). Deviating somewhat from his previous assertions, he stated that the debilities afflicting the less-privileged could be achieved by a national policy of "sanitary engineering" (AZEVEDO, 1933, p. 46). Aspects of this policy would include the reorganization of the school environment and curriculum, and the redefinition of the role of physical activities in the academic program. His adherence to the general maxim "to sanitize is to eugenize" was consistent with his promulgation of the school discipline of Physical Education as a means of regenerating the less-favored populations of Brazil.

In his work Novos Caminhos e Novos Fins (1932), Azevedo drew upon eugenic ideas when proposing changes in public primary school education. He advocated the construction of ample and appropriate school buildings complete with laboratories, workshops and gymnasiums; and the expansion of School Hygiene practices that included organized physical activities involving students in sensory activities, games, gymnastics and organized sports. As a respected and influential spokesman for change of the educational system, Azevedo was successful in promoting and framing the debate about the formative effects of educational physical activities on the children of Brazil. 


\section{Bibliography}

ADAMS, M. "Eugenics in the History of Science" In: ADAMS, M. The Wellborn Science: Eugenics in Germany, France, Brazil, and Russia. New York: Oxford University Press, 1990

AZEVEDO, F. Da Educação Physica: o que ella é - a que tem sido - o que deveria ser. São Paulo: Weiszflog Editores, 1920.

AZEVEDO, F. Novos Caminhos e Novos Fins. A Nova Política de Educação no Brasil. SP. Melhoramentos, 1932.

AZEVEDO, F. “O problema da regeneração”. Revista Educação Physica, 1933, n. 5

BARBOSA, R. Reforma do ensino primário e várias instituições complementares da instrução pública. Rio de Janeiro: Fundação Casa de Rui Barbosa, v. X, tomo IV, 1982.

GONDRA, J. "Medicina, higiene e educação escolar.” In: LOPES, E.M.T.; FARIA FILHO, L.M. \& VIEGA, C.G. 500 anos de educação no Brasil. Belo Horizonte: Autentica, $2^{a}$ edição, 2000.

LIMA, N. T. \& HOCHMAN, G. "Condenado pela raça, absolvido pela medicina. O Brasil pelo movimento sanitarista da Primeira Republica". In: Maio, M C. \& Santos, R. V. (orgs). Raça, ciência e sociedade. Rio de Janeiro: Fiocruz, Centro Cultural Banco do Brasil, 1996.

LORENZ, K; VECHIA, A.; FERREIRA, A. "Hygienization" and the Schooling of the Less-Privileged Classes in Brazil, 1880-1920. Paper presented at the 30th Session of the International Standing Conference for the history of Education (ISCHE). Rutgers University, Newark, New jersey, July 2008.

MASIERO, A. “A psicologia racial no Brasil (1918-1929)”. Estudos de Psicologia, 10(2), 2005.

MONCORVO FILHO, C. A. Histórico da protecção à infância no Brasil 1500-1922. Rio de Janeiro: Impreza Graphica Editora, 1926.

ROMERO, S. America Latina. Porto: Livraria Ohardon, 1906.

SCHNEIDER, W. The Eugenics Movement in France. In: ADAMS, M. The Wellborn Science: Eugenics in Germany, France, Brazil, and Russia. New York: Oxford University Press, 1990,

STEPAN, N. Eugenics in Brazil: 1917-1940. In: Adams, Mark. The Wellborn Science: Eugenics in Germany, France, Brazil, and Russia. New York: Oxford University Press, 1990. 
VECHIA, A; LORENZ, K. Fernando de Azevedo e a questão da "raça brasileira": sua regeneração pela educação física. Cadernos de Historia da Educação. Uberlandia, Editora da Universidade de Uberlandia, Brazil, vol. 8, no. 1, jan-jun, 2009, pp. 57-70.

ZUCOLOTO, P. C. S. V. O médico higienista na escola: as origens históricas da medicalização do fracasso escolar". Revista brasileira de crescimento e desenvolvimento humano. São Paulo, v. 17. no. 1, abr. 2007.

\footnotetext{
${ }^{1}$ Doutor em Educação pela Columbia University, New York. Professor de Pós-Graduação de Sacred Heart University, Fairfield, Connecticut, U.S.A. Contato: lorenzk@sacredheart.edu
}

Artigo recebido em: 20/9/2009

Aprovado para publicação em: 30/9/2009 